\title{
25 Research Soure \\ Tiredness of Life in Older Persons: An Evolutionary Concept Analysis
}

\section{Liesbeth Van Humbeeck}

Ghent University Hospital https://orcid.org/0000-0002-8321-5001

\section{Femke Driedijk}

AZ Nikolaas

\section{Sarah De Mey}

AZ Maria Middelares

\section{Reine De Bock}

Universitair Ziekenhuis Gent

Ruth Piers ( ruth.piers@uzgent.be )

Ghent University Hospital Corneel Heymanslaan 10

Nele Van Den Noortgate

Universitair Ziekenhuis Gent

\section{Research article}

Keywords: definition, concept analysis, tiredness of life, older adults, literature review

Posted Date: December 4th, 2020

DOI: https://doi.org/10.21203/rs.3.rs-120466/v1

License: (c) (i) This work is licensed under a Creative Commons Attribution 4.0 International License.

Read Full License 


\section{Abstract}

\section{Background}

Older adults face accumulated vulnerabilities that can make day-to-day life a constant struggle. This may lead to the feeling that the story of their life has come to an end and a persistent death wish. In this context tiredness of life has become a widely used term, but remains a poorly understood concept in healthcare. This study seeks to review the health-related literature on tiredness of life and to identify attributes, antecedents and consequences of the concept.

\section{Methods}

A concept analysis of the scientific literature in the health disciplines was performed using Rodgers' evolutionary method. Four databases (Pubmed, Web of Science, CINAHL and EMBASE) were searched (January 2000-September 2019).

\section{Results}

Thirty-three publications were included. Four defining attributes (being weary of life, motivational depletion, loss of meaning in life and an inability to connect to ones' life), four antecedents (the experience of unpredictable circumstances, experienced age-related life struggles, the fear of dependency and social redundancy), and three consequences (euthanasia requests, voluntary refusal to eat and drink and suicide) were identified. Concepts such as 'finished with life', 'suffering from life' and 'completed life' were used interchangeably both in public debate as among health care providers and patients.

\section{Conclusions}

International consensus definition on "tiredness of life" is currently lacking. Analysis of its defining attributes and antecedents provides important information related to its impact and potential risk factors. Clearly, more work is needed to grasp the experience of tiredness of life.

\section{Background}

Increasing percentages of individuals will live longer periods of their life with physical and mental impairments that may impoverish their perceived sense of well-being [1,2]. Consequently, older persons may long for their biographical life to coincide neatly with their biological life, in order to avoid a sense of living too long or experiencing a social death [3-5]. In recent years, there has been a growing interest in older persons wishing to die without the presence of a life-threatening disease or a severe psychiatric disorder [6-8]. Prior research $[5,6,9]$ has shown that around $3 \%$ of older persons have either a current desire to die or a reduced desire to continue living. Another recent study in the Netherlands showed that $1.34 \%$ of older persons (55+) has a persistent desire to die of which $0.77 \%$ actively wishes to end their lives without having a serious underlying condition [10]. The Berlin Aging Study (BASE) showed that there is a parallel increase in prevalence of tiredness of life and suicidality with increasing age [11]. 
Healthcare providers are in a key position to assist older individuals in their adaptation to life changes and are increasingly confronted with tiredness of life [12]. Therefore, it is important for them to understand how a wish to die and tiredness of life are related to each other. However, in the field of research about the wish to die in older people who suffer from life, there is a lack of consistency in conceptualization. This lack of clarity reflects the complexity and ambiguity of the issue at stake. A concept analysis (CA) may advance the understanding of tiredness of life, especially when the attributes or characteristics of the phenomenon are not well delineated [13]. As a clear definition and meaning of the concept is lacking on an international level, this CA aims to clarify what is currently known as tiredness of life. The analysis identifies the components of tiredness of life and may serve as a base for further conceptual development.

\section{Method}

Concept analysis (CA) aims to provide a working definition and clarification of the concept being analysed [14]. Rodgers (2000) contends that a clearly clarified concept may be used more effectively and its strengths and weaknesses evaluated. Variations can be introduced and tested, moving towards the development of a more useful concept, reflecting a contemporary context for its use. For this CA a review of the literature was executed and Rodgers evolutionary method of concept analysis was used. This method was chosen because of the emphasis on the fact that a concept is context dependent and dynamic. In the evolutionary view, the content of a concept is not composed of a fixed set of conditions constituting an everlasting 'truth' of the concept. On the contrary, a concept is considered as a basis for further development as it evolves over time by convention or purposeful redefinition. This CA method was also chosen for its focus on the collection and analysis of raw data rather than the construction of "cases" as is proposed in other CA approaches [15].

\section{Data sources}

A search strategy was drafted by LVH with training in geriatrics and systematic literature review methodology. After discussion with SDM and FD, a final search strategy for all databases was agreed upon. The literature search was performed by two authors (SDM and FD). The key search concepts were 'tiredness of life' and 'older persons'. Related terms, synonyms and abbreviations of these key search concepts were used in the search strategy and combined with one of the Boolean operators 'OR' and 'AND'. A detailed search strategy used for searching publications in Pubmed is displayed in Table 1. Publications were searched in the following databases: Pubmed, Web of Science, CINAHL and EMBASE. The Pubmed search strategy was modified accordingly to search the other databases. Searches were limited to Dutch, French and English language publications only and dated from January 2000 until December 2019. This timeframe was chosen to ensure that retrieved articles were recent and relevant to the current healthcare context. Hand searching of the reference lists of obtained articles to identify publications not indexed in electronic databases was performed. 
All types of publications were included (e.g. research papers, position statements, opinion papers and editorials). Only publications in English and Dutch were retained. During the title/abstract screening process, all sources containing one of the synonyms of tiredness of life were retained. During the full text screening, only publications containing one or more of the following components of Rodgers' evolutionary model of CA as shown in Table 2 were retained: attributes, related concepts, surrogate terms, antecedents or consequences. References were excluded if no abstract was available. Publications on the topic without reference to care for older persons were excluded.

\section{Data Collection, Management and Analysis}

Two reviewers (SDM and FD) independently screened a random selection of titles and abstracts that represented $10 \%$ of the total number of retrieved references. A first screening was done based on title. In case of doubt, the screening was based on the abstract. In case of disagreement between the two reviewers, a third in-dependent reviewer $(\mathrm{LVH})$ decided on inclusion or exclusion. All retained publications were read at least twice by SDM and FG prior to data extraction, which allowed them to become acquainted with the data and to label data based on the major components of Rodgers' evolutionary method. The aim of data analysis in concept analysis is to identify a consensus in the literature (Rodgers, 2000). Data extraction was facilitated by the use of a self-developed data extraction sheet that contained the author(s), publication year, type of publication and the country of relevance. The data extraction sheet also consisted of the major components of Rodgers' method of concept analysis. All sections of full text articles containing relevant information were copied into the applicable categories of the data extraction sheet. Once all relevant data were identified, each items was read to obtain a general tone and re-read a number of times to ensure all relevant data were extracted. Questions for each category were formulate to guide the data analysis process (Table 2). Consequently, thematic analysis was performed. Central themes were identified separately for each data category covering a major component of the CA.

\section{Results}

The search of the databases initially generated 1143 records. After duplicate removal in Endnote 642 records were screened for title and abstract. Eligibility for full text inclusion was assessed for 48 articles, of which 4 were excluded as they did not contain any information on attributes, roles, antecedents or consequences of tiredness of life. Another 6 publications were excluded due to their focus on a nongeriatric population. The reference lists of obtained articles and books were reviewed and key citations which appeared across reference lists were obtained. Finally, no full text could be retrieved of 5 publications. In total, 33 publications were included in this review (Table 3). Results of the screening and selection of publications are shown in Fig. 1.

\section{Attributes of Tiredness of Life}

\section{Definition}


In current literature just one definition of tiredness of life could be retrieved. In this definition being tired of life refers to psychological suffering caused by the prospect of having to continue living with a very poor quality of life, not predominantly caused by a physical or psychiatric disease, and closely associated with a death wish. Although the presence of suffering is crucial in the definition of tiredness of life $[16,17]$, older people being tired of life don't decisively take steps to end their life $[18,19]$. Besides a definition, a number of terms emerged from the literature as attributes of tiredness of life. Each will be discussed below.

\section{Attributes}

First, tiredness of life is characterized by the idea of 'being weary of life' as a feeling of boredom and a lack of meaningful daytime activities [20]. Older persons feel physically and mentally fatigued and are no longer able to give resistance at all. The second attribute that has been consistently referred to is the loss of meaning in life $[5,21]$. Older persons attest of having no reason for existence as well as have the feeling of not pursuing worthwhile goals and having no mission or a sense of direction in life. Third, authors refer to an inability and unwillingness to connect to one's life [22] as feelings of extreme social disconnection or isolation under the heading of thwarted belonginess [23]. Fourth, scholars refer to tiredness of life as a an ongoing non-linear process containing fluctuations in well-being, health, autonomy and relatedness [24].

\section{Surrogate Terms}

Rodgers (2000) describes surrogate terms as other words or phrases which are used interchangeably to describe the concept being examined. Concepts such as 'finished with life', 'completed life', 'existential suffering from disconnectedness in old age' and 'suffering from life' are used interchangeably both in the public debate and among physicians and patients. The main difference between these terms concerns the presence of a death wish in varying degrees (e.g. persistent, passive or active). Finished with life refers to 'the situation of people, usually of an advanced age but not suffering from any medical disease or condition that is untreatable or a cause of severe suffering, who have determined for themselves that their own quality of life has diminished to such an extent that they prefer death over life' [25].The term completed life is used to describe the situation of an older person who considers his or her life completed and, instead of waiting for a natural death, desires to conclude it $[18,26]$. Completed life refers to an existential suffering as a consequence of a negative conditional determination of the current quality of life. This concept emphasizes that a person prefers death over life without prevailing suffering. The suggestion of some scholars that suffering can only emerge when life is 'completed' does not accurately reflect the complex issue of older persons who are suffering from life. A 'completed life' refers to people who go a step further: rather than waiting for a natural death, they decide to end life by active means (with or without help)'.The phenomenon is further understood as: "a tangle of inability and unwillingness to connect to one's life" [6]. A permanent tension is experienced as daily experiences seem to be incompatible with a person's expectations of life and their idea of whom they are. Existential suffering from disconnectedness in old age specifically refers to older persons who are no longer able or unwilling 
to connect to life resulting in an experience of life as no longer worth living without evidence of severe physical and mental disease. In this description older persons feel separated from others and view themselves as not mattering [27]. Suffering from life is referred to as fundamental in tiredness of life across much of the literature "suffering under the prospect of having to continue life at a profound diminished level of quality, which results in persistently recurring longing for death, without being able to determine a somatic or psychological reason" Suffering of this type can result from the feeling that life is 'complete', but it may also have other causes [25]. It refers to the personally experienced threat, not excluding physical, emotional, existential or even social suffering. The concept "suffering from life" is not age-related [25].

\section{Related Concepts}

Related concepts are "concepts that bear some relationship to the concept of interest but do not seem to share the same set of attributes" (Rodgers, 2000; p.92). Examples of such concepts are: wish to hasten death, existential loneliness, demoralization and balance sheet suicide.

\section{A Wish to Hasten Death (WTHD)}

This wish occurs as a reaction to suffering in the context of a life-threatening physical condition from which the patients sees no way out than accelerating the dying process [28]. However, others also use this term not restricted to terminally ill persons who hasten their death by voluntary refusal of food and fluid. This wish to hasten death is a response to physical/psychological/spiritual suffering, loss of self, fear of dying, the desire to live but not in this way (i.e. a sort of cry for help). The experience of a WTHD is associated with a sense of time running out. The fear of causing loved ones to suffer and the expectation of a future in which they would be a burden to others were primary motives for wanting to end their lives, even in patients who were not suffering at that particular moment in time [29]. WTHD is seen as a way of ending suffering, as a kind of control over one's life (the sense of control comes from having a hypothetical exit plan [30,31] and a way of ending the loss of self and dignity [32]. This wish may vary in intensity in time [32].

\section{Existential Loneliness}

Existential loneliness can be understood as 'the immediate awareness of being fundamentally separated from other people and from the universe, primarily through experiencing oneself as mortal, or, and especially when in a crisis, experiencing not being met at a deep human (i.e. authentic" level" [33, 34]. Frail older persons have described existential loneliness as being related to feeling trapped in a frail and deteriorating body, being met with indifference, having nobody to share life with and lacking purpose and meaning $[35,36]$.

\section{Demoralization}

Demoralization is a syndrome of existential distress occurring in patients suffering from mental or physical illness, specifically ones that threaten life or integrity of being. Demoralization is a clinical state 
of low morale and triggered by poor coping with impending death, characterized by hopelessness, helplessness, loss of purpose, feelings of entrapment, and potential desire to suicide [37]. Studies show a prevalence of $15 \%$ among oncology patients, rising to $30 \%$ in palliative care $[38,39]$. It occurs in the context of a severe threat that causes marked anxiety, in which the person does not know the solution. Demoralization boils down to a perception of a loss of direction, role or sense of purpose leading to feelings of pointlessness [40]. In $14 \%$ of patients demoralization occurs in the absence of an affective, anxiety or adjustment disorder and may contribute to an increased risk for suicidal ideation beyond the effect of mental disorders [41].

\section{Balance Sheet Suicide or Rational Suicide}

As one ages, the negative points accumulate to such an extent that death becomes preferable to life [42, 43]. In this context, the suicidal act is seen as a logical outcome of a balance sheet. In the past this type of suicide was described as an "enduring wish to die in a person with a condition of enduring unbearable physical and/or emotional pain, no hope for improvement. The person, who is not mentally disturbed, makes a free will decision which would not cause "unnecessary or preventable harm" to others." [44].

\section{Antecedents}

The antecedents of a concept are those events that generally occur before occurrence of the concept (Rodgers, 1989). A number of antecedents, which must be in place in order for tiredness of life to occur, were identified in the literature. These antecedents are situated on an individual and societal level with a mutual reinforcing effect $[16,20,45]$.

On individual level, tiredness of life is initiated by an older person's impossibility to deal with experienced age-related losses (physical deterioration, loss of function, incontinence, cognitive impairment, among others) [46]. The loss of bodily control may comprise a wish to die if one feels objectified, perceiving a loss of 'self' [47]. Others state that tiredness of life is underpinned by a lack of meaningful daytime activities initiating a feeling of boredom. For some older persons not being able to do the things that brought meaning and value to their life may be a reason to wish for its end [5]. Becoming increasingly dependent gives older persons a sense of no longer belonging to "the world of agency and choice" [48]. Often older persons feel frustrated and guilty about being an emotional/physical or financial burden for their family members and/or healthcare providers. Tiredness of life can thus represent a desire to spare others from suffering [49]. A recurring theme is the fear of dependency on others, not being able to be useful anymore (i.e. social redundancy), not experiencing a level of reciprocity and losing control over their life $[20,36]$. Overall, this is connected to an older person's coping style and life orientation [50]. The realization that there is a great discrepancy between the desired situation and the actual situation - in addition combined with an experienced loss of control to achieve the desired situation - may lead to tiredness of life.

On societal level, perceptions of old age or physical decline shape the way we see ourselves, and may lead to deep suffering [51]. It seems that the idea that life is no longer worth living is partly constituted by 
a societal idea that old-age dependencies compromise one's autonomy and dignity (van Wijngaarden et al., 2015a). Currently, an abjection of frailty exists that lends itself to the process of othering resulting in a failure to acknowledge the subjective agency of an older person [52]. The concept tiredness of life challenges the current discourse of successful and positive aging $[53,54]$ as a process of continuous adjustment to new - restricting - circumstances [55].

\section{Consequences of Tiredness of Life}

The loss of meaning and existential suffering accompanying tiredness of life may, but not necessarily, evolve to a pertinent death wish (Barnow \& Linden, 1996; Dewey, Davidson \& Copeland, 1993; Linden \& Barnow, 1997). Most older adults keep living their lives with their death wish in compliance with their faith or because a self-willed end simply does not fit their personality. Others decide to continue living as they place greater weight upon a natural course of the dying process [24]. For some, voluntary stopping of eating and drinking (VSED) is described as a method to control the timing and circumstances of their death [56]. For a minority, the feelings of hopelessness and despair may progress to suicidal ideation, suicide plans, attempts and ultimately completion of the act $[8,57]$. Finally, some older persons actively take steps towards ending one's life or to a formal euthanasia request as a right of self-determination [22, 24]. The most pronounced increase in euthanasia requests is in those 80 years or older and residing in nursing homes (2.0\% to $4.6 \%$ between 2007 and 2013). Being tired of life is in $25.3 \%$ of euthanasia deaths the most important rationale. [58]. These developments show a change in society in the direction of more self-empowerment and even towards a right to die [26, 59,60]. Current debate revolves around seeing old-age vulnerability and the accumulation of comorbidities as the result of compounded medical and non-medical problems as unbearable and incurable suffering as defined under the Euthanasia Act $[61,62]$.

\section{Discussion}

The purpose of this article was to review the health-related literature on tiredness of life and to identify the defining attributes, antecedents, and consequences of the concept. Our paper reveals the current immaturity of the concept. Up to this point, we have demonstrated that tiredness of life cannot be understood without taking into account the socio-cultural context and the moral understandings as the background against which older people define themselves, act in relation to others and understand the world. Our results show that tiredness of life is a complex phenomenon which consists of a cluster of emotions, thought constructs and actions in which concerns for others play an important role.

Life is a call to be answered by the personal will to go on writing one's personal biography, be it a next chapter or only the epilogue [63]. From our review it remains unclear whether tiredness of life is a clear "responsive refusal" to the call of life or rather the powerless incapacity, the loss of being able to respond tout court. The related wish to die might also mask a desire to live a different life. The question can only be raised here whether the dynamic interplay between call and response can possibly be reopened and revitalized in some way or another [64]. This CA stresses that antecedents of tiredness of life are situated 
both on individual and societal level. Clearly by focussing exclusively on individual characteristics and behaviours, we risk blaming individuals for not achieving resilience in later life. So we must pay adequate attention to the broader physical and social contexts that underpin and foster individual resilience [65]. Rather, it should be put in a wider perspective and focus on the question of how to build an inclusive society, (re)establish trust, and minimize the impact of inherent vulnerabilities and situational dependencies on the lives of older people [27]. This is in line with the thoughts of Tillich (2000) who described the essence of how to feel connected in terms of either taking part or being a part of, where both aspects are needed in order to feel connected in life [66]. This calls for an enabling individual mindset as well as an enabling social response [67]. However, this requires a process of changing internal standards and values and the reconceptualization of the concept quality of life in older persons [68]. Instead a life course perspective may broaden this conceptualization by acknowledging that diverse experiences may lead to varying interpretations of success, both individually and culturally [69]. The findings from this CA point to several areas for further research. Clearly, more work is needed to grasp the full potential of tiredness of life. Concept analysis is never an end in itself; rather, it stimulates continuous concept development [15]. The development of concepts must be rooted in empirical knowledge, and new developments must be evaluated. Clinical clarity is essential as it could provide a kind of 'toolkit' to people concerned by tiredness of life. Assessment and measurement of the concept would be enhanced by the addition of qualitative measures designed to capture individualized personal constructs related to tiredness of life. Furthermore, the attributes, antecedents and consequences establish a theoretical framework that may be applied in the development of tools to assess tiredness of life. Often tiredness of life is implicit; thus, incorporating tools to assess for this phenomenon must tap for underlying presence. Future steps include further qualitative research to enhance the definition development, possible development of an instrument to measure tiredness of life, and eventually testing of the effectiveness of nursing interventions to alleviate tiredness of life.

\section{Limitations}

As this CA is the first analysis specifically focusing on tiredness of life, it gives an overview and state of the art of the components identifying the concept. However some limitations need to be addressed. First, the search timeframe (e.g. 2000-2019) may have limited the ability to identify more differences in how the term tiredness of life was used over time. Second, the inclusion of publications in no other languages than English, French and Dutch could have led to an incomplete analysis of tiredness of life. Third, our analysis used a principle-based analysis and didn't explore the concept by using the method of conceptualization of meaning, which involves identifying the usage of tiredness of life in a variety of media (including the popular literature) (Chinn \& Kramer 2011).

\section{Conclusion}

This concept analysis was undertaken to clarify the concept of tiredness of life. Although the review uncovered one definition and several attributes of tiredness of life such as a feeling of boredom, a loss of 
meaning in life, an inability and unwillingness to connect to one's life and an ongoing non-linear process, an international consensus definition regarding tiredness of life is lacking. Future research needs to concentrate on (1) enhancing definition development, (2) development of an instrument to measure tiredness of life, and eventually (3) testing the effectiveness of interventions to alleviate tiredness of life.

\section{Declarations}

Ethics approval and consent to participate

Not applicable

Consent for publication

Not applicable

Availability of data and materials

All data generated or analyzed during this study are included in this published article [and its supplementary information files].

Competing interests

The authors declare that they have no competing interests.

\section{Funding}

This research received no specific grant from any funding agency in the public, commercial, or non-profit sector.

Authors' contributions

All authors conceived and designed the article. LVH, FD, SDM conducted the literature review and analysis. RDB, RP andNVDN significantly contributed to the theoretical concept and analysis. LVH drafted the text, all authors revised and approved the manuscript.

Acknowledgements

Not applicable

\section{References}

1. Dennis $M$, Baillon S, Brugha T, Lindesay J, Stewart $R$, Meltzer $H$ : The influence of limitation in activity of daily living and physical health on suicidal ideation: results from a population survey of Great Britain. Soc Psychiatry Psychiatr Epidemiol 2009, 44(8):608-613. 
2. Torres S, Hammarstrom G: Speaking of 'limitations' while trying to disregard them: A qualitative study of how diminished everyday competence and aging can be regarded. J Aging Stud 2006, 20(4):291-302.

3. Coleman PG, O'Hanlon A: Aging and development. Social and emotional perspectives. London: Routledge; 2017.

4. Fleming J, Farquhar M, Brayne C, Barclay S: Death and the Oldest Old: Attitudes and Preferences for End-of-Life Care-Qualitative Research within a Population-Based Cohort Study. PLoS One 2016, 11(4): $\mathrm{e} 0150686$.

5. Rurup ML, Deeg DJ, Poppelaars JL, Kerkhof AJ, Onwuteaka-Philipsen BD: Wishes to die in older people: a quantitative study of prevalence and associated factors. Crisis 2011, 32(4):194-203.

6. van Wijngaarden E, Leget C, Goossensen A: Ready to give up on life: The lived experience of elderly people who feel life is completed and no longer worth living. Soc Sci Med 2015, 138:257-264.

7. Ayalon L: The prevalence and predictors of passive death wishes in Europe: a 2-year follow-up of the Survey of Health, Ageing, and Retirement in Europe. Int J Geriatr Psychiatry 2011, 26(9):923-929.

8. Raue PJ, Morales KH, Post EP, Bogner HR, Have TT, Bruce ML: The wish to die and 5-year mortality in elderly primary care patients. Am J Geriatr Psychiatry 2010, 18(4):341-350.

9. Onwuteaka-Philipsen B, Kox RMK, Pasman HR, Huisman WA: Inzicht in ouderen met een wens om te sterven of een verminderde wens om te leven: een crosssectionele studie op basis van het LASAcohort.Nederlands-Vlaams Tijdschrift voor Palliatieve Zorg 2019, 16(3):174-175.

10. Van Wijngaarden E, van Thiel GJ, Hartog I, van den Berg V, Zomers M, Sachs A, Uiterwaal C: Het PERSPECTIEF-onderzoek. Perspectieven op de doodswens van ouderen die niet ernstig ziek zijn: de mensen en de cijfers. In. Den Haag: ZonMw; 2020.

11. Barnow S, Linden M: Epidemiology and psychiatric morbidity of suicidal ideation among the elderly. Crisis 2000, 21(4):171-180.

12. Van Humbeeck L, Dillen L, Piers R, Van Den Noortgate N: Tiredness of Life in Older persons: A Qualitative Study on Nurses' Experiences of Being Confronted With This Growing Phenomenon. Gerontologist 2019.

13. Walker L, Avant K: Discourse on concept analysis. Journal of Holistic Nursing 2005, 23:11-12.

14. Rodgers BL: Concept analysis: An evolutionary view. In: Concept development in nursing Edited by B. L. Rodgers KAK. Philadelphia, PA: W.B. Saunders; 2000: 77-102.

15. Rodgers BL: Concepts, Analysis and the Development of Nursing Knowledge - the Evolutionary Cycle. J Adv Nurs 1989, 14(4):330-335.

16. Van Den Noortgate N, Vanden Berghe J, De Lepeleire J, Ghijsebrechts G, Lisaerde J, Beyen A: Oud en moe van dagen: levensmoeheid bij ouderen Tijdschrift voor Geneeskunde 2016, 72(3):145-157.

17. Delbeke E: Juridische aspecten van zorgverlening aan het levenseinde. Antwerpen: Intersentia; 2012.

18. Peters M: Completed life. What are we talking about ? . Amsterdam: NVVE; 2010. 
19. van Rein PS: Petitioning for completed life: A thematic content analysis. . Minneapolis: Walden University; 2013.

20. Rurup ML, Pasman HR, Goedhart J, Deeg DJ, Kerkhof AJ, Onwuteaka-Philipsen BD: Understanding why older people develop a wish to die: a qualitative interview study. Crisis 2011, 32(4):204-216.

21. van Wijngaarden E, Goossensen A, Leget C: The social-political challenges behind the wish to die in older people who consider their lives to be completed and no longer worth living. J Eur Soc Policy 2018, 28(4):419-429.

22. Florijn BW: Extending' euthanasia to those 'tired of living' in the Netherlands could jeopardize a wellfunctioning practice of physicians' assessment of a patient's request for death. Health Policy 2018, 122(3):315-319.

23. Eades A, Segal DL, Coolidge FL: Suicide Risk Factors Among Older Adults: Exploring Thwarted Belongingness and Perceived Burdensomeness in Relation to Personality and Self-Esteem. Int J Aging Hum Dev 2019, 88(2):150-167.

24. Defesche F: Voltooid leven in Nederland. Assen: Van Gorcum; 2011.

25. KNMG: Op zoek naar normen voor het handelen van artsen bij vragen om hulp bij levensbeeindiging in geval van lijden aan het leven: rapport Commissie Dijkhuis. . Utrecht: KNMG; 2014.

26. Kessler C: A Completed Life. Survival 2018, 60(3):231-234.

27. van Wijngaarden E: Ready to give up on life: A study into the lived experience of older people who consider their lives to be completed and no longer worth living. PhD Dissertation. Utrecht: University of Humanistic Studies Utrecht; 2016.

28. Balaguer A, Monforte-Royo C, Porta-Sales J, Alonso-Babarro A, Altisent R, Aradilla-Herrero A, BellidoPerez M, Breitbart W, Centeno C, Cuervo MA et al: An International Consensus Definition of the Wish to Hasten Death and Its Related Factors. PLoS One 2016, 11(1):e0146184.

29. Rodriguez-Prat A, Balaguer A, Crespo I, Monforte-Royo C: Feeling like a burden to others and the wish to hasten death in patients with advanced illness: A systematic review. Bioethics 2019, 33(4):411420.

30. Monforte-Royo C, Sales JP, Balaguer A: The wish to hasten death: Reflections from practice and research. Nurs Ethics 2016, 23(5):587-589.

31. Monforte-Royo C, Villavicencio-Chavez C, Tomas-Sabado J, Balaguer A: The wish to hasten death: a review of clinical studies. Psychooncology 2011, 20(8):795-804.

32. Rodriguez-Prat A, Balaguer A, Booth A, Monforte-Royo C: Understanding patients' experiences of the wish to hasten death: an updated and expanded systematic review and meta-ethnography. BMJ Open 2017, 7(9):e016659.

33. Hemberg J, Nyqvist F, Nasman M: "Homeless in life" - loneliness experienced as existential suffering by older adults living at home: a caring science perspective. Scand J Caring Sci 2019, 33(2):446-456.

34. Bolmsjo I, Tengland PA, Ramgard M: Existential loneliness: An attempt at an analysis of the concept and the phenomenon. Nurs Ethics 2019, 26(5):1310-1325. 
35. Kitzmuller G, Clancy A, Vaismoradi M, Wegener C, Bondas T: "Trapped in an Empty Waiting Room"The Existential Human Core of Loneliness in Old Age: A Meta-Synthesis. Qual Health Res 2018, 28(2):213-230.

36. Sjoberg M, Beck I, Rasmussen BH, Edberg AK: Being disconnected from life: meanings of existential loneliness as narrated by frail older people. Aging Ment Health 2018, 22(10):1357-1364.

37. An E, Lo C, Hales S, Zimmermann C, Rodin G: Demoralization and death anxiety in advanced cancer. Psychooncology 2018, 27(11):2566-2572.

38. Jacobsen JC, Maytal G, Stern TA: Demoralization in medical practice. Prim Care Companion J Clin Psychiatry 2007, 9(2):139-143.

39. Robinson S, Kissane DW, Brooker J, Burney S: A Review of the Construct of Demoralization: History, Definitions, and Future Directions for Palliative Care. Am J Hosp Palliat Care 2016, 33(1):93-101.

40. Clarke DM, Kissane DW: Demoralization: its phenomenology and importance. Aust N Z J Psychiatry 2002, 36(6):733-742.

41. Vehling S, Kissane DW, Lo C, Glaesmer H, Hartung TJ, Rodin G, Mehnert A: The association of demoralization with mental disorders and suicidal ideation in patients with cancer. Cancer 2017, 123(17):3394-3401.

42. Gramaglia C, Calati R, Zeppegno P: Rational Suicide in Late Life: A Systematic Review of the Literature. Medicina (Kaunas) 2019, 55(10).

43. Joiner TE, Hom MA, Hagan CR, Silva C: Suicide as a derangement of the self-sacrificial aspect of eusociality. Psychol Rev 2016, 123(3):235-254.

44. Diekstra RF: The significance of Nico Speijer's suicide: how and when should suicide be prevented? Suicide Life Threat Behav 1986, 16(1):13-15.

45. van Wijngaarden E: Voltooid leven. Maatwerk 2012, 13(3):22-24.

46. Lapierre S, Boyer R, Desjardins S, Dube M, Lorrain D, Preville M, Brassard J: Daily hassles, physical illness, and sleep problems in older adults with wishes to die. Int Psychogeriatr 2012, 24(2):243-252.

47. Truchard ER, Monod S, Jox RJ: The wish to die in elderly nursing homes residents. Journal of the American Geriatrics Society 2018, 66:S113-S113.

48. De Lange F: Loving later life: an ethics of aging. Grand Rapids, Michigan: William B. Eerdmans Publishing Company; 2015.

49. Guidry ET, Cukrowicz KC: Death ideation in older adults: psychological symptoms of depression, thwarted belongingness, and perceived burdensomeness. Aging Ment Health 2016, 20(8):823-830.

50. Tilvis RS, Laitala V, Routasalo P, Strandberg TE, Pitkala KH: Positive life orientation predicts good survival prognosis in old age. Arch Gerontol Geriatr 2012, 55(1):133-137.

51. Abrams D, Russel PS, Vauclair M, Swift HJ: Ageism in Europe: Findings from the European Social Survey. London: AgeUK; 2011.

52. Gilleard C, Higgs P: Ageing abjection and embodiment in the fourth age. J Aging Stud 2011, 25(2):135-142. 
53. Dillaway HE, Byrnes M: Reconsidering Successful Aging A Call for Renewed and Expanded Academic Critiques and Conceptualizations. J Appl Gerontol 2009, 28(6):702-722.

54. Pack R, Hand C, Rudman DL, Huot S: Governing the ageing body: explicating the negotiation of 'positive' ageing in daily life. Ageing Soc 2019, 39(9):2085-2108.

55. von Faber M, Bootsma-van der Wiel A, van Exel E, Gussekloo J, Lagaay AM, van Dongen E, Knook DL, van der Geest S, Westendorp RGJ: Successful aging in the oldest old - Who can be characterized as successfully aged? Arch Intern Med 2001, 161(22):2694-2700.

56. Saladin N, Schnepp W, Fringer A: Voluntary stopping of eating and drinking (VSED) as an unknown challenge in a long-term care institution: an embedded single case study. BMC Nurs 2018, 17:39.

57. Kim YA, Bogner HR, Brown GK, Gallo JJ: Chronic medical conditions and wishes to die among older primary care patients. Int J Psychiatry Med 2006, 36(2):183-198.

58. Dierickx S, Deliens L, Cohen J, Chambaere K: Comparison of the Expression and Granting of Requests for Euthanasia in Belgium in 2007 vs 2013. JAMA Intern Med 2015, 175(10):1703-1706.

59. Kouwenhoven PSC, van Thiel G, van der Heide A, Rietjens JAC, van Delden JJM: Developments in euthanasia practice in the Netherlands: Balancing professional responsibility and the patient's autonomy. Eur J Gen Pract 2019, 25(1):44-48.

60. Blommendaal P, van de Vathorst S: Euthanasia for completed life. Huisarts en Wetenschap 2017, 60(2):71-74.

61. Deliens L, van der Wal G: The euthanasia law in Belgium and the Netherlands. Lancet 2003, 362(9391):1239-1240.

62. Rurup ML, Onwuteaka-Philipsen BD, Jansen-van der Weide MC, van der Wal G: When being 'tired of living' plays an important role in a request for euthanasia or physician-assisted suicide: patient characteristics and physician's decision. Health Policy 2005, 74:157-166.

63. Freeman M: Narrative foreclosure in later life: Possibilities and limits. In: Storying later life: Issues, investigations and interventions in later life Edited by G. K, E. B, L. RW. New York: Oxford University Press; 2011: 3-19.

64. de Lange F: Responsive Aging. An Existential View. In: Aging and Human Nature. Edited by Schweda M, M. C, C. B, vol. 25. London: Springer; 2020: 173-190.

65. Wiles JL, Wild K, Kerse N, Allen RES: Resilience from the point of view of older people: 'There's still life beyond a funny knee'. Soc Sci Med 2012, 74(3):416-424.

66. Tillich P: The courage to be. New Haven, CT: Yale University Press; 2000.

67. Winterrowd E, Canetto SS, Benoit K: Permissive beliefs and attitudes about older adult suicide: a suicide enabling script? Aging Ment Health 2017, 21(2):173-181.

68. Raijmakers NJ, van der Heide A, Kouwenhoven PS, van Thiel GJ, van Delden JJ, Rietjens JA: Assistance in dying for older people without a serious medical condition who have a wish to die: a national cross-sectional survey. J Med Ethics 2015, 41(2):145-150. 
69. Stowe JD, Cooney TM: Examining Rowe and Kahn's Concept of Successful Aging: Importance of Taking a Life Course Perspective. Gerontologist 2015, 55(1):43-50.

\section{Tables}

Table 1. Search Strategy with MeSH terms and free Text words for PUBMED*.

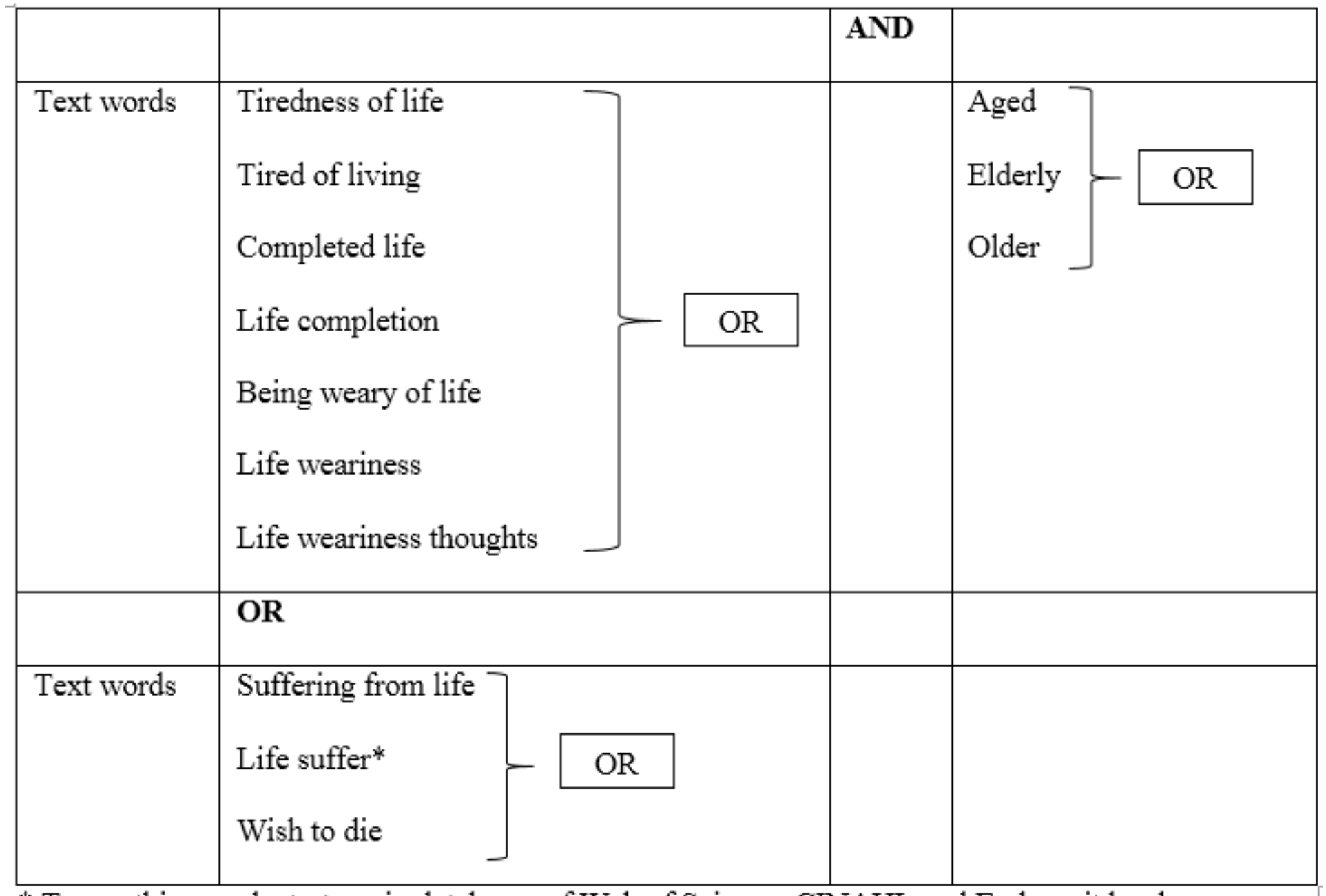

* To use this search strategy in databases of Web of Science, CINAHL and Embase it has been modified accordingly

Table 2. Guiding Questions Used During Data Analysis Phase 


\begin{tabular}{|ll|}
\hline $\begin{array}{l}\text { Category } \\
\begin{array}{l}\text { Surrogate } \\
\text { terms }\end{array}\end{array}$ & Guiding question \\
\hline $\begin{array}{l}\text { Related } \\
\text { concepts }\end{array}$ & Does this term bear any relationship to tiredness of life ? \\
\hline Attributes & $\begin{array}{l}\text { What are the characteristics of tiredness of life as outlined in this paper? What is } \\
\text { the author discussing/describing? }\end{array}$ \\
\hline Antecedents & What happens before tiredness of life occurs? \\
\hline Consequences & What happens as a result of tiredness of life? \\
\hline
\end{tabular}

\section{Table 3. Characteristics of All Included Articles $(n=33)$}




\begin{tabular}{|c|c|c|c|c|}
\hline Author, year & Country & $\begin{array}{l}\text { Discipline first } \\
\text { author }\end{array}$ & Type of reference & Contribution \\
\hline An et al., 2017 & Canada & Medicine & Quantitative study & D \\
\hline Ayalon, 2010 & Israel & Social work & Quantitative study & $D, F$ \\
\hline Balaguer et al., 2016 & Spain & Medicine & Literature review & D \\
\hline Barnow \& Linden, 1996 & Germany & Psychiatry & Quantitative study & $\mathrm{F}$ \\
\hline $\begin{array}{l}\text { Blommendaal et al., } \\
2017\end{array}$ & $\begin{array}{l}\text { The } \\
\text { Netherlands }\end{array}$ & Primary care & Opinion paper & $D, E, F$ \\
\hline Clarke et al., 2002 & Australia & Psychiatry & Literature review & C, D \\
\hline Dewey et al., 1993 & USA & Psychiatry & Quantitative study & $D, F$ \\
\hline Florijn, 2018 & $\begin{array}{l}\text { The } \\
\text { Netherlands }\end{array}$ & Medicine & Opinion paper & $C, D, F$ \\
\hline Gramaglia et al., 2019 & Italy & Psychiatry & Literature review & D \\
\hline Jacobsen et al., 2006 & USA & Primary care & Quantitative study & D \\
\hline Jorm et al., 1995 & Australia & Psychiatry & Quantitative study & D \\
\hline Kessler, 2018 & USA & Public health & Opinion paper & $\mathrm{C}, \mathrm{F}$ \\
\hline Kim et al., 2006 & USA & Primary care & Quantitative study & D \\
\hline Lapierre et al., 2012 & Canada & Psychiatry & Survey study & $B, D, F$ \\
\hline Linden \& Barnow, 1997 & Germany & Psychiatry & Qualitative study & $A, D, F$ \\
\hline $\begin{array}{l}\text { Monforte-Royo et al., } \\
2011\end{array}$ & Spain & Medicine & Literature review & $B, D$ \\
\hline $\begin{array}{l}\text { Monforte-Royo et al., } \\
2016\end{array}$ & Spain & Medicine & Opinion paper & B \\
\hline Monforte-Royo, 2012 & Spain & Medicine & Literature review & $B, D$ \\
\hline Rajmakers et al., 2015 & $\begin{array}{l}\text { The } \\
\text { Netherlands }\end{array}$ & Public health & Survey study & $A, D, F$ \\
\hline Raue et al., 2010 & USA & Psychiatry & Quantitative study & D \\
\hline $\begin{array}{l}\text { Rodriguez-Prat et al., } \\
2017\end{array}$ & Spain & Medicine & Literature review & $B, D$ \\
\hline $\begin{array}{l}\text { Rodriguez-Prat et al., } \\
2019\end{array}$ & Spain & Medicine & Literature review & D \\
\hline Rodriguez-Prat, 2017 & Spain & Medicine & $\begin{array}{l}\text { Philosophical } \\
\text { review }\end{array}$ & D \\
\hline Rurup et al., 2005 & The & $\begin{array}{l}\text { Public health } \\
\text { Page } 17 / 20\end{array}$ & Quantitative study & $B, C, E, F$ \\
\hline
\end{tabular}




\begin{tabular}{|lllll|}
\hline Rurup et al., 2011 & $\begin{array}{l}\text { Netherlands } \\
\text { The } \\
\text { Netherlands }\end{array}$ & Public health & Qualitative study & C, E \\
\hline Rurup et al., 2011 & $\begin{array}{l}\text { The } \\
\text { Netherlands }\end{array}$ & Public health & Qualitative study & B \\
\hline Rurup et al., 2011 & $\begin{array}{l}\text { The } \\
\text { Netherlands }\end{array}$ & Public health & Quantitative study & B \\
\hline Truchard et al. 2018 & $\begin{array}{l}\text { Switzerland } \\
\text { Van Den Noortgate et al., }\end{array}$ & Medicine & $\begin{array}{l}\text { Mixed methods } \\
\text { study }\end{array}$ & B, D \\
\hline 2016 & Medicine & Literature review & A, B, C, F \\
\hline $\begin{array}{l}\text { Van Wijngaarden et al., } \\
2014\end{array}$ & $\begin{array}{l}\text { The } \\
\text { Netherlands }\end{array}$ & Ethics & Literature review & C, D \\
$\begin{array}{l}\text { Van Wijngaarden et al., } \\
2015\end{array}$ & $\begin{array}{l}\text { The } \\
\text { Netherlands }\end{array}$ & Ethics & Qualitative study & B, C, D, F \\
$\begin{array}{l}\text { Van Wijngaarden et al., } \\
2016\end{array}$ & $\begin{array}{l}\text { The } \\
\text { Netherlands }\end{array}$ & Ethics & Qualitative study & B,F \\
\hline $\begin{array}{l}\text { Van Wijngaarden et al., } \\
2017\end{array}$ & $\begin{array}{l}\text { The } \\
\text { Netherlands }\end{array}$ & Ethics & Opinion paper & B, E, F \\
\hline
\end{tabular}

A, definitions; B, antecedents; C, attributes: $\mathbf{D}$, related concepts; $\mathbf{E}$, surrogate terms; $\mathbf{F}$, consequences

Figures 


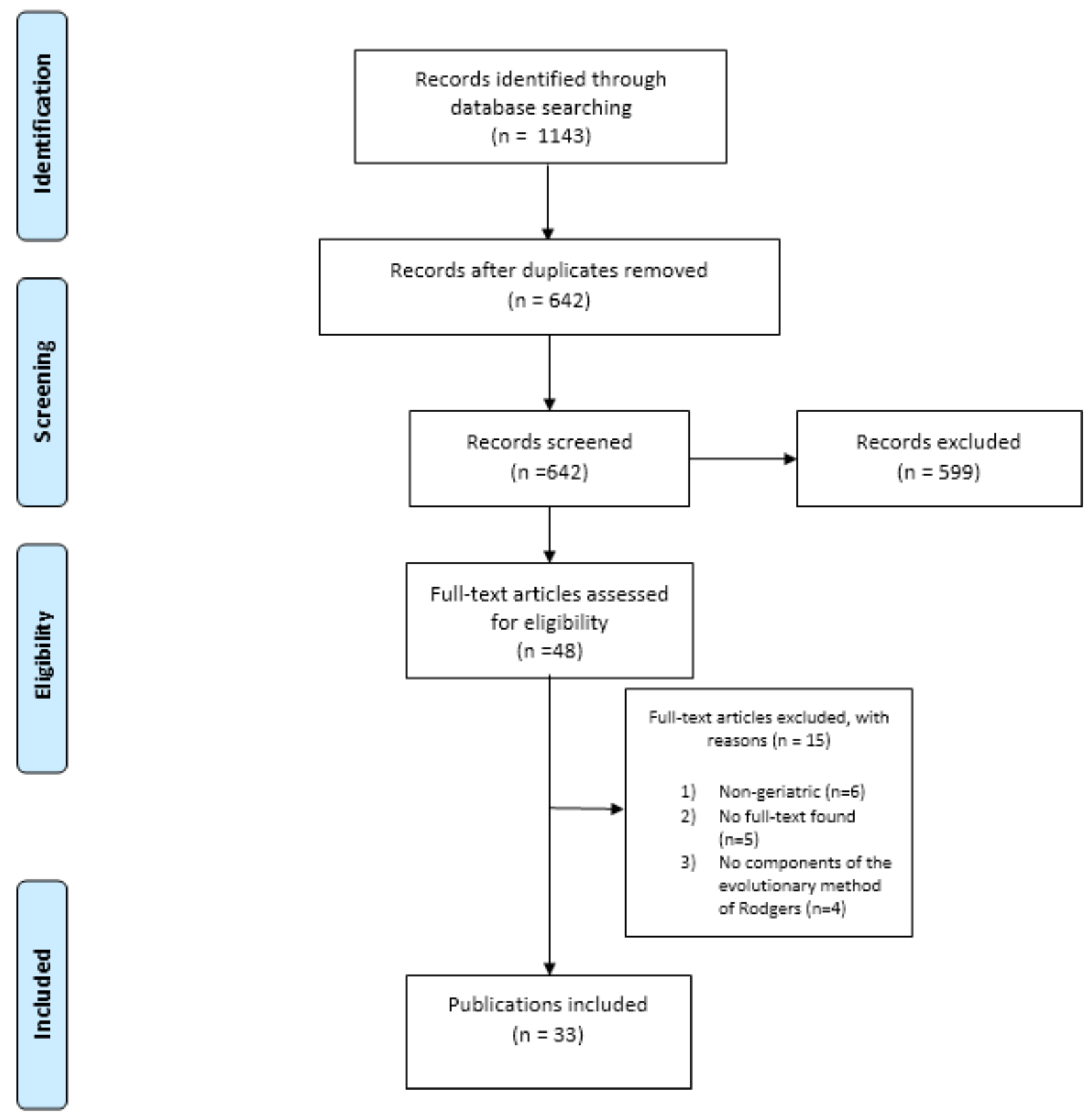

Figure 1

Flow Diagram of Included Publications 


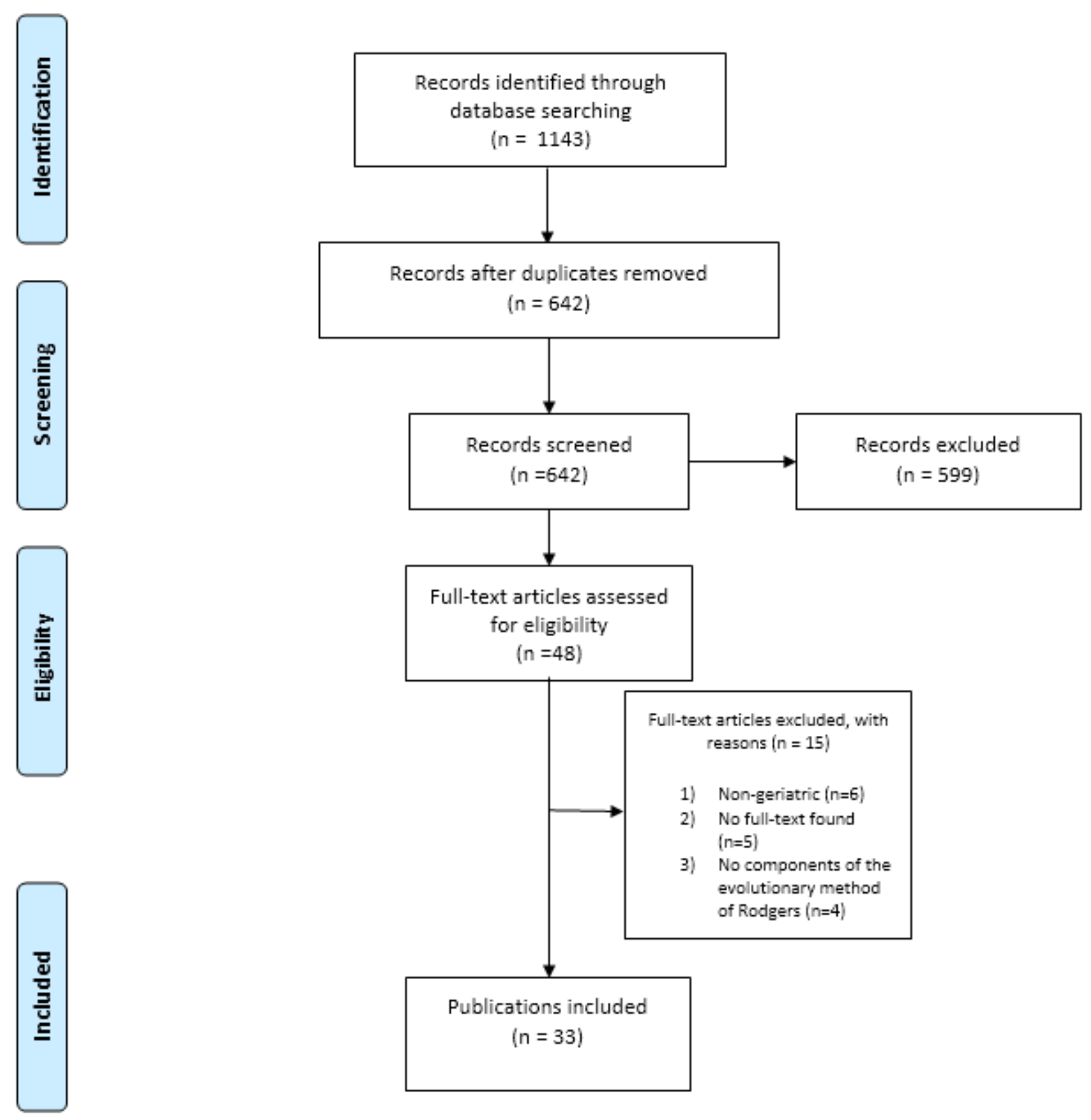

Figure 1

Flow Diagram of Included Publications

\section{Supplementary Files}

This is a list of supplementary files associated with this preprint. Click to download.

- PRISMA2009ChecklistMSWord.doc

- PRISMA2009ChecklistMSWord.doc 